\title{
Dominance Relationships in Female Groups of Red Deer: Seasonal Changes
}

\author{
Juan CARRANZA
}

\begin{abstract}
Carranza J., 1988: Dominance relationships in female groups of red deer: seasonal changes. Acta theriol., 33, 31: 435-442. [With 2 Tables \& 2 Figs].
\end{abstract}

A study is made on agonistic interactions and dominance relationships in female groups of wild red deer (Cervus elaphus L.), in terms of age-sex classes, and comparing the periods before and after the rut A decrease in interaction rates and the arising of reversals was found from pre-breeding to post-breeding. Seasonal changes are discussed in relation to availability of resources and development of individuals.

[Cátedra de Biología. y Etología. Facultad de Veterinaria. Universidad de Extremadura. 10071 Cáceres, Spain].

\section{INTRODUCTION}

The existence of dominance hierarchies between red deer hinds (Cervus elaphus L.) has been described and related to age and body size (Hall, 1983; Clutton-Brock et al., 1986). The stability of these dominance relationships has also been reported (Thouless \& Guinness. 1986). While a relative stability in hierarchical relationships between males or even between adult females is not a surprising fact, in family groups a slightly different situation could be expected. The costs and benefits of a given position in a hierarchical order is partly shared by members of a family group by means of their inclusive fitness.

It is known that a dominant animal may give up some of the advantages of a high rank to younger animals due to its own increase in inclusive fitness, as is the case of central positions in social spacing for this same species (Carranza \& Arias de Reyna, 1987).

In a non-kin group, the hierarchical arrangement is the result of a conflict between individual interests. Within a family group, however, the inclusive component of fitness must also be weighted to understand the final arrangement. The result may be almost the same as that coming from a cooperative group. Moreover, the cost/benefit ratio of a given hierarchical position for each animal changes throughout development, and therefore hierarchies must be expected to change too.

According to Trivers (1972) hinds probably compete mainly for food resources, and rank is important mainly in displacement at a feeding 
site. The benefits of a high rank must therefore decrease as resource availability increases. Both development and resource availability could promote seasonal changes in hierarchies and agonistic interactions.

This paper reports on the hierarchical organization and the agonistic interactions within female groups of red deer at two different periods of the year (before and after the rut) which represent extremes with regard to resource availability and some changes have already occurred in development.

\section{METHODS}

The study area lies in central Sierra Morena (Córdoba, Spain) and consists of mediterranean scrub and forest, of which certain areas have been reclaimed as pastureland.

Data were obtained in the periods before and after the rut (pre-breeding and post-breeding, respectively), since during the rut (September-October) females are usually grouped in harems. The following age-sex classes were considered: (1) Calves: animals up to one year of age, regardless of sex;(2) Yearling females: covering the second year of life, up to the calving period; (3) Young hinds (two-year-old females); corresponding to the third year of life; (4) Hinds: females over three years old; (5) Yearling males: corresponding in age to the yearling females class, and including all males showing their first set of antlers.

Data were collected by direct observation and by using portable video equipment, according to the focal group (or subgroup) method (Altmann, 1974), from hidden observatories, during 157 hours in the pre-breeding and 102 in the post-breeding periods. An amount of 669 individuals (not individually recognized) were observed in the pre-breeding and 1,420 in the post-breeding periods, in familiar groups or aggregates of several families.

On the basis of the interactions recorded, action-reception matrices were constructed for threats (including nose and ear threats, displacements, kicks, bites, and chases) and flights. Appleby's (1983) "winter-loser" test of linearity was applied to matrices, $k$ being the linearity index, and $d$ the number of reversals (Appleby, 1983).

Action and reception rates were calculated as a function of the total observation time for each class, and their intervals of confidence were calculated as proportions (Spiegel, 1961). The comparison of interaction frequencies between seasons was made by using the chi-square test, applied to matrices of $2 \times 2$ with frequencies for each age-sex class in both seasons and the expected frequencies according to the relative time of observation.

The proportion comparison test (Spiegel, 1961) was employed for the study of relations between classes, using as a statistic the typified normal distribution which was termed $\mathrm{z}$. Expected proportions were calculated according to the amount of observation (time per pair of individuals) for each pair of classes, as described in the method proposed by Altmann \& Altmann (1977). The study of relationships was carried out in accordance with two criteria: (1) considering as a total the sum of the action-reception matrix, thus enabling significant relations to be obtained from the matrix as a whole; (2) studying each class as actor and receiver. 
the totals in this case being those of the rows and columns respectively, thus providing significant relations for each class, independently of what these might represent in terms of the matrix as a whole.

\section{RESULTS}

Rates of threats and flights diminish from pre-breeding to post-breeding as the mean group size increases (Table 1), as a consequence of the gathering of family groups in the post- breeding period (Table 2).

Table 1

General rates of interactions (per individual in $100 \mathrm{mi}-$ nutes) and mean group size in both periods of study, $\mathrm{N}=$ number of groups.

\begin{tabular}{lcccc}
\hline \multicolumn{1}{c}{ Season } & Threats & Flights & $\begin{array}{c}\text { Mean group } \\
\text { size }\end{array}$ & $\mathrm{N}$ \\
\hline Pre-breeding & 5.57 & 3.04 & 2.38 & 281 \\
Post-breeding & 2.08 & 1.71 & 4.88 & 291 \\
\hline
\end{tabular}

Table 2

Percentage of family groups and aggregates of several families in both periods of study. $\mathrm{N}=$ number of groups.

\begin{tabular}{lcccc}
\hline \multirow{2}{*}{ Season } & \multicolumn{3}{c}{$\%$ of groups } & \\
\cline { 2 - 5 } & Familiar & Non-familiar* & Indeterminate & N \\
\hline Pre-breeding & 82.92 & 14.95 & 2.13 & 281 \\
Post-breeding & 48.45 & 48.80 & 2.75 & 291 \\
\hline
\end{tabular}

* Based on the presence of at least two individuals from the same age-sex class.

Matrices of the frequency with which each age-sex class performed and received both threats and flights were used as a basis for the application of Appleby's (1983) linearity test. The results obtained in both periods of study were as follows:

$k=1(d=0)$ both for threats $(\mathrm{N}=176)$ and flights $(\mathrm{N}=96)$ in the pre-breeding period, with a ranking from dominant to subordinate animals: hind, yearling male, young hind, yearling female, calf.

$k=0.65(d=1.75)$ for threats $(\mathrm{N}=135)$ and flights $(\mathrm{N}=111)$ in the post-breeding period, with the following (non-linear) class order: yearling male, hind, young hind, yearling female, calf. 
Since only 5 age-sex classes were considered it was not possible to test the significance of the linearity index (see Appleby, 1983). However, in the case of the pre-breeding period, the fact that $k$ reached maximum value and $d=0$ indicated that the order clearly tends towards linearity. In the post-breeding period, on the other hand, the index value obtained does not suggest the existence of a linear order.

Interaction rates per unit time for each class and for the two periods of study are shown in Fig. $1(\mathrm{a}-\mathrm{d})$. It can be seen that threat performance rates tend to diminish for most classes frcm pre-breeding to post-breeding, a decrease not found for yearling males and young hinds (Fig. 1a). Threat rates tend to be higher in those classes occupying an intermediate position in the dominance hierarchy, diminishing towards both ends of the arrangement (Fig. 1a), a phenomenon also found for flight reception

a performing threats

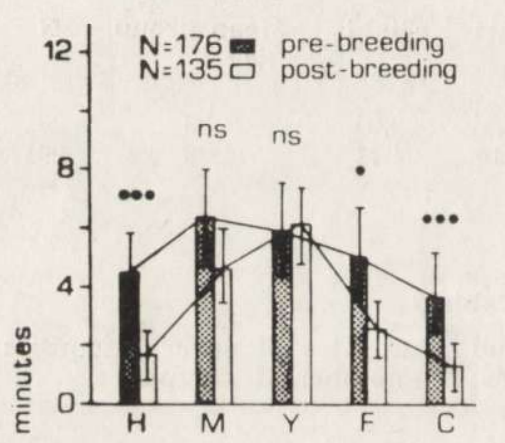

응

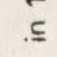

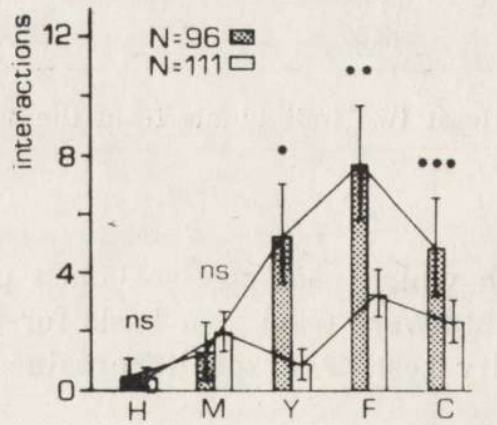

b) receiving threats

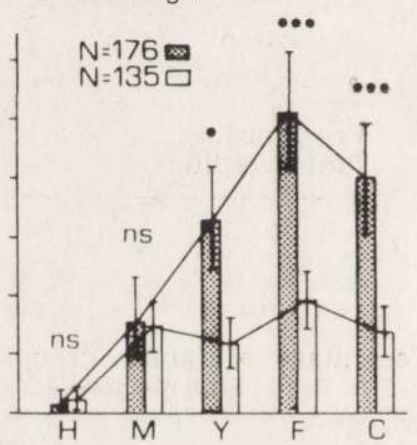

d) receiving flights

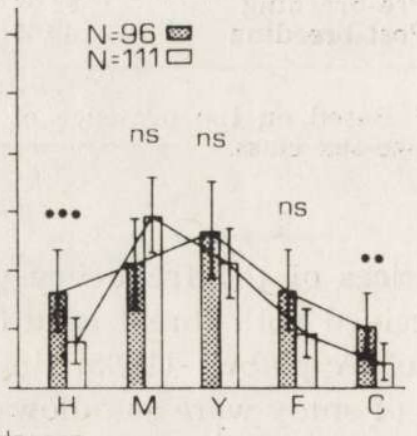

Fig. 1. Interaction rates (threats and flights) for age-sex clases in both periods of study. Intervals of confidence at $95 \%$ and comparison between seasons based on chi-square test $\left({ }^{* * *} p<0.001 ;{ }^{* *} p<0.01 ;{ }^{*} p<0.05\right)$. Age-sex classes in decreasing order according to dominance hierarchy in pre-breeding. $\mathrm{H}$ - Hind; $\mathrm{M}$ - Yearling male; $\mathrm{Y}-$ Young hind; $\mathrm{F}-$ Yearling female; $\mathrm{C}-$ Calf. $\mathrm{N}=$ number of interctions. 
rates (Fig. 1d). Threat reception rates, on the other hand (Fig. 1b), increase lower down the dominance scale of the pre-breeding period, when the hierarchy tends towards linearity, although they decrease for the calf class. Similar relations were found in the post-breeding period, but they tend to be lower with the exception of yearling males (Fig. 1b). The same general pattern is found for flight performance, though yearling males are again an exception (Fig. 1c).

The directionality of interactions is shown in Fig. 2. Threats seem tc occur preferentially among adjacent classes in the dominance hierarchy, and from adult hind to yearling female. Interaction directions follow the dominance order for pre-breeding (when this is linear) but less clearly for post-breeding, when some significant interactions appear in the reverse order. Interactions between individuals from the same age-sex class were common for the youngest animals (calves, yearling males, yearling females).

THREATS

PRE-BREEDING

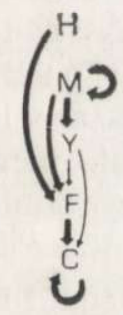

POST BREEDING

$\mathrm{H}$

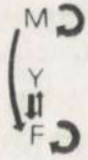

$U^{c}$
FLIGHTS

PRE BREEDING

POST-BREEDING

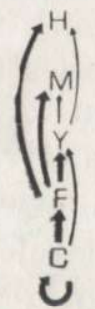

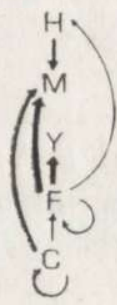

Fig. 2. Sociograms showing positive and significant values of $z$, which indicate favoured directions for the performance of threats and flights in both periods of study. Age-sex classes in decreasing order according to hierarchy in pre-breeding. (Age-sex classes as in Fig. 1). Significance of $z$ : $-p<0.05$; $p<0.01$

In order to study interaction performance and reception directions in classes with low interaction rates, the interactions performed or received by each of the classes independently were considered as totals for the calculation of proportions. The results thus obtained did not represent any substantial modification to what has already been described, and therefore they are not included here, the only noteworthy relation was that between hind and yearling male. The proportion of threats received by a hind from a yearling male was higher than expected from the amount of time that the yearling male had been observed close to the hind $(z=4.19 ; p<0.001)$. 


\section{DISCUSSION}

In mediterranean ecosystems, the two periods chosen for this study represent extremes for the red deer with regard to resource availability. Resources are scarce in the pre-breeding period (summer and early autumn) and plentiful in the post-breeding period (winter and spring, see Rodriguez Berrocal, 1978).

The general decrease found in interaction rates reflects a less competitive situation in post-breeding, probably due to the high resource availability, a finding also reported by Hall (1983) and Clutton-Brock et al. (1986) for red deer hinds in Rhum, although in that case the timing of resource availability is the reverse (higher in summer). When the level of competition is low, the optimal group size must increase due to the benefits of vigilance, specially when animals are exploiting resources in open habitats as is the case of red deer during the post-breeding period in our study area (Carranza, 1984). When benefits of a high rank are low, the maintenance of a status becomes less important and hierarchical order may lose linearity.

When classes are ordered according to rank, the interaction rates produce polygons with shapes that are meaningful. As is the general case reported for many species including red deer (Clutton-Brock et al., 1982, 1986; Hall, 1983), rates of performing threats are low in the extremes of the ranking, and rates of receiving threats increase down the hierarchical order; the opposite being the case for flight rates.

Particular stages in development produce features reflected in interaction rates. Thus, calves receive less threats than could be expected from their rank, probably due to their spatial proximity to hinds (Carranza \& Arias de Reyna, 1987). Young hind and yearling male do not share the general situation of decrease in interaction rates from pre-breeding to post-breeding. Although agonistic interactions may not be very important for most classes in the post-breeding season, this may not be the case for young hinds and yearling males, both classes are approaching the time of separation from the matriarchal group. The young hind is probably pregnant for the first time and will separate in the next May or June, and the yearling male is going to join all-male groups where the development of agonistic interactions and the maintenance of a high rank is highly correlated to reproductive success (Clutton-Brock et al., 1982).

The development of agonistic interactions and social relationships in general must be important during the post-breeding season when different family groups aggregate in open areas, allowing young individuals to interact towards those from their own age-sex class from 
different families, engaging themselves in agonistic and play interactions. Apart from differences between age-sex classes in the benefits associated with the maintenance of a high rank, hinds must have been selected to allow their offspring from the previous year to maintain a high rank in family groups when it is important for their development, and future social behaviour, and means a low cost for the remaining members.

Thus, and bearing in mind the importance of rank specially for males, the change in dominance relationships between hind and yearling male could be explained as a result of (1) sexual dimorphism that enables yearling male to threat even adult females, (2) differences in the benefits of rank between individuals of different age or sex producing asymmetries in the profitability of escalating during contests, (3) a yielding by a hind which benefits herself by means of her offspring's fitness. Nevertheless, there is no evidence for red deer to the effect of such surrendering on future relationships, though for some species social prior-experience has been proved to have an effect on future relationships. Thus, prior dominance experience may increase the probability of winning future contests, and furthermore, prior subordinate experience seems to have a stronger effect in decreasing such a probability (see Beacham \& Newman, 1987, for a recent review). It would be interesting to test this influence in red deer.

Hierarchical organization between females has been reported to be stable through the years (Thouless \& Guinness, 1986), this fact is not in disagreement with the results presented here of seasonal changes that may reflect only a seasonal fine tune of agonistic interactions, probably reflecting both the costs-benefits of rank and the effect of inclusive fitness for each member of a family group.

\section{REFERENCES}

1. Altmann J., 1974: Observational study of behaviour: Sampling methods. Behaviour, 49: 227-267.

2. Altmann S.A. \& Altmann J., 1977: On the analysis of rates of behaviour. Anim. Behav., 25: 364-372.

3. Appleby M.C., 1983: The probability of linearity in hierarchies. Anim. Behav., 31: $600-608$.

4. Beacham J.L. \& Newman J.A., 1987: Social experience and the formation of dominance relationships in the pumpkinseed sunfish, Lepomis gibbosus. Anim. Behav., 35: 1560-1563.

5. Carranza J., 1984: Organización y estructura, diferenciación de comportamientos y configuración espacial, en el sistema social del ciervo (Cervus elaphus L.). Ph. D. Thesis. Univ. of Extremadura.

6. Carranza J. \& Arias de Reyna L., 1987: Spatial organization of female groups 
in red deer (Crevus elaphus L.). Behav. Processes, 14: 125-135.

7. Clutton-Brock T.H., Albon S.D. \& Guinness F.E., 1986: Great expectations: dominance, breeding success and offspring sex ratios in red deer. Anim. Behav., 34: 460-471.

8. Clutton-Brock T.H., Guinness F.E. \& Albon S.D., 1982: Red deer. Behaviour and ecology of two sexes. Edinburgh Univ. Press., 1-378.

9. Hall M.J., 1983: Social organization in an enclosed group of red deer (Cervus elaphus) on Rhum. I. The dominance hierarchy of females and their offsprings. Z. Tierpsychol., 61: 250-262.

10. Rodriguez Berrocal J., 1978: Introducción al estudio y valoración de los recursos forestales y arbustivos para el ciervo en el área ecológica de Sierra Morena: I, Estudio de la dieta del ciervo. Arch. Zootec., 27: 73-82.

11. Spiegel M.R., 1961: Estadistica. McGraw-Hill ed., 1-357.

12. Thouless C.R. \& Guinness F.E., 1986: Conflict between red deer hinds: the winner always wins. Anim. Behav., 34: 1166-1171.

13. Trivers R.L., 1972: Parental investment and sexual selection. [In: „Sexual Selection and the Descent of Man" 1871-1971, Ed. B, Campbell]. Chicago: Aldine. 136-179.

Received 3 December 1987, Accepted 6 April 1988.

Juan CARRANZA

\section{STRUKTURA DOMINACYJNA W GRUPIE SAMIC JELENI - ZMIANY SEZONOWE}

\section{Streszczenie}

Zbadano interakcje antagonistyczne oraz strukturę dominacji w grupach lań u jeleni, Cervus elaphus Linnaeus, 1758 , porównując okresy przed i po rui oraz uwzględniając klasy plci i wieku.

Wykryto spadek liczby interakcji agresywnych (Ryc. 1) oraz zmianę struktury dominacji w okresie po rozrodzie, w stosunku do okresu przed rozrodem (Ryc. 2). Dyskutowane są zmiany sezonowe obserwowanych parametrów w odniesieniu do dostępności zasobów pokarmowych oraz zmian rozwojowych poszczególnych klas wieku. 